\title{
Race and Character in Cien años de soledad
}

\author{
For Andy \\ Adelaida López-Mejía ${ }^{1}$
}

The depiction of race in Cien años de soledad/One Hundred Years of Solitude merits careful analysis, since Gabriel García Márquez's magical realist novel is set in a multiracial Caribbean society. The seventeen sons of Colonel Aureliano Buendía are identified as mixedrace, dark-skinned, or mulato men, thus highlighting the overlap between illegitimacy and miscegenation in Latin America. These male characters are not developed with the care or complexity with which the narrator characterizes the legitimate Buendía males. Female characters of African descent in the novel are more carefully developed than their male counterparts, but their characterization is marred by unfortunate stereotypes associating women of color with animalistic and promiscuous sexuality. Nevertheless the biracial character of Petra Cotes is memorable for her ethical complexity and valor. [Article copies available for a fee from The Transformative Studies Institute. E-mail address: journal@transformativestudies.org Website: http://www.transformativestudies.org (C2013 by The Transformative Studies Institute. All rights reserved.]

KEYWORDS: Race, Character, García Márquez, Solitude.

Cien años de soledad has been viewed through many prisms but in critical readings of the novel there is very little focus on the question of race. The narrative arguably presents the novel's events through a European filter, or Pseudo-European presumed whiteness. ${ }^{1}$ A reading that is sensitive to race shows that racial mixture most often intersects with illegitimacy in Cien años de soledad. White women are instrumental in policing racial hierarchy; black women are relegated to

\footnotetext{
${ }^{1}$ Adelaida López-Mejía is a professor of Latin American Literature and Spanish Language at Occidental College in Los Angeles. She has published four psychoanalytic essays on the work of Gabriel Garcia Marquez, which have appeared in Revista Hispanica Moderna, Bulletin of Hispanic Studies, MLN, and Revista de Estudios Hispánicos. She is currently working on the representation of race in García Márquez's fiction. Address correspondence to: Adelaida López-Mejía; e-mail: adela@oxy.edu.
} 